This is an Accepted Manuscript of a book chapter published by Routledge in the book:

"The Routledge International Handbook of Violence Studies".

Published IN 2019.

Book available online:

https://www.routledge.com/The-Routledge-International-Handbook-of-ViolenceStudies-1st-Edition/DeKeseredy-Rennison-Hall-Sanchez/p/book/9781138283442 


\title{
Violence and Indigenous Communities
}

Cunneen, C. and Tauri, J. (2019) 'Violence and Indigenous Communities', in DeKeseredy, W., Rennison, C. and A. Hall- Sanchez (eds) The Routledge International Handbook of Violence Studies, Routledge, New York. ISBN 9781138283442, pp 350-361

\begin{abstract}
This chapter focuses on violence and Indigenous peoples in the Anglo settler colonial states of Aotearoa New Zealand, Australia, Canada and the United States. Indigenous activists and scholars in the Anglo settler colonial states have long tackled the complex issues contributing to the high rates of violence occurring in some Indigenous communities. However, mainstream debates on violence tended to be constrained in their conceptualisations of violence (notably missing are references to racist violence and state violence) and continue to be dominated by colonising discourses of pathology, tribalism and barbarity. We seek to move beyond the restricted focus on Indigenous peoples' so-called 'problem' with violence and to provide a more nuanced and critical interpretation of the complex relationship between Indigenous people and violence.
\end{abstract}

KEYWORDS: Indigenous, violence, colonialism, state violence, violence against women

\section{Introduction: Taking a broad definition of violence}

This chapter focusses on violence and Indigenous peoples in the Anglo settler colonial states of Aotearoa New Zealand, Australia, Canada and the United States. Within and between these settler colonial jurisdictions there are substantial differences among Indigenous peoples. A common complaint made by Indigenous scholars is the lack of recognition of Indigenous diversity within nation states and globally (Walter, 2016). Indeed, the four states noted above are home to an estimated 9 million Indigenous peoples from hundreds of different Indigenous nations (Cunneen \& Tauri, 2016, pp. 2-4), and these are a relatively small fraction of the estimated 370 million Indigenous peoples globally (United Nations, 2009, p. 1). Thus, generalisation is a perilous and potentially misleading task. However, despite cultural, linguistic and historical variations, Indigenous peoples in the Anglo settler 
colonial states share some broad common experiences around colonisation and contemporary problems related to the protection of their rights as distinct peoples. There are also some common threads in the racialisation of Indigenous peoples (that is, the social, legal and political construction of Indigenous peoples as racially inferior to the colonisers) and the contemporary disproportionate rates of criminalisation they experience (see Tauri, 2016).

Indigenous activists and scholars in the Anglo settler colonial states have long tackled the complex issues contributing to the high rates of violence occurring in some Indigenous communities. However, mainstream debates on violence tended to be constrained in their conceptualisations of violence (notably missing are references to racist violence and state violence) and continue to be dominated by colonising discourses of pathology, tribalism and barbarity (for further discussion see Cunneen and Rowe, 2016, pp. 114-6). Further, there is a persistent and disturbing silencing and invalidation of Indigenous voices, knowledges and experiences in both policy development and criminological research (Deckert, 2015; Tauri, 2014). Misguided policy solutions have been based on a restricted definition of violence; a continuation of the dominant relationship between the colonised and the colonisers; and the perpetuation of a 'deficit-based' approach to the 'Indigenous problem' (see Walter \& Anderson (2013) on deficit-based approaches to Indigenous people).

While being cognisant of issues related to interpersonal violence in Indigenous communities, and particularly violence against women, we seek to move beyond the restricted focus on Indigenous peoples' so-called 'problem' with violence. This chapter therefore takes a broad analysis of violence which includes:

- interpersonal violence and violence against women;

- colonial violence and its long-term impact on the contemporary position of Indigenous people;

- epistemic violence; that is, the denial of Indigenous knowledges and viewpoints, or as Spivak (1988, pp. 280-281) notes, the denial of a position from which the subaltern, the marginalized, the oppressed can speak;

- racist violence and racial discrimination; and 
- state violence against Indigenous people, including the violence and neglect in custodial environments, and Indigenous deaths in custody.

Thus, we seek in this chapter to provide a more nuanced and critical interpretation of the complex relationship between Indigenous people and violence. A broad approach to understanding violence in Indigenous communities is consistent with some current inquiries into the issue, including the Canadian National Inquiry into Missing and Murdered Indigenous Women and Girls [NIMMIWG] (2017).

\section{Policing Interpersonal Violence and Violence against Women}

It is well established that criminal victimisation rates for Indigenous peoples are much higher than the rates found in the general population. In Aotearoa New Zealand, Māori are 9 percentage points more likely to experience criminal victimisation than the average rate of victimisation (33 per cent compared to 24 per cent), and Māori are more than twice as likely to be the victim of intimate partner violence than the average rate (Ministry of Justice, 2015, p. 71). A study by the Bureau of Justice Statistics found that American Indians are much more likely to become victims of violent crime than any other group, experiencing violent crime at a rate of one in 10, or twice that of the general population (Perry, 2004, p. iv). In Canada, some 28 per cent of Aboriginal people reported being a victim of crime in the previous twelve months compared to 18 per cent of non-Aboriginal people (Boyce, 2016). Aboriginal people were more than twice as likely to report being victims of violent crime than non-Aboriginal people (Boyce, 2016). With reporting of victimisation comes engagement with the agents of criminal justice, most notably the police. It is to this relationship, most especially the argument that Indigenous peoples are oversurveilled and under-supported by police that we now turn, before returning to the specific issue of violence against Indigenous women.

\section{Policing Violence in Indigenous Communities}

Much of the critical analysis of the causes of violence that occurs in Indigenous communities invariable focus on the seemingly contradictory issues of excessive surveillance (over-policing) and underwhelming support (under-policing). In the first instance, it is argued that a significant amount of violence and conflict occurs during interactions between police and Indigenous individuals and communities (Cunneen, 
2001; South Australian Council of Social Services, 2015). On the other hand, some forms of conduct do not receive the amount of official attention that reflects the impact it has on the community (Ben-Porat, 2008).

The phenomenon of the under-policing of violent crime in Indigenous communities has been widely commented upon since the 1990s (for example, in Canada, the Royal Commission on Aboriginal Peoples, 1996, p. 88). Under-policing refers to the lack of response to issues affecting Indigenous communities where law enforcement or legal assistance is required. How this problem plays out varies to some extent depending on the jurisdiction. For example, the complicated system of policing on Indian country in the US where criminal jurisdiction may be exercised by three separate governmental systems - federal, state and tribal - adds to the problem of under-policing (International Indian Treaty Council, 2007, p. 28).

In the US under-policing is also exacerbated by the failure to adequately fund tribal justice systems, the sporadic and inconsistent investigation and prosecution by state and federal law enforcement (where applicable) on Indian country, and the particular problems of (interracial) violence and violence against women in urban areas and border towns adjacent to Indian reservations (Perry, 2008; National Indian Youth Council, 2013, pp. 8-10). One area where under-policing occurs is with hate crimes. Perry (2008) found that in the US only 10 per cent of hate crimes perpetrated against American Indians were reported to police. She found that the low reporting was the result of the historical and contemporary experiences with police and the view that police do not take American Indian victimization seriously.

The problem of under-policing has also been noted in Canada where Aboriginal people are often seen as 'less worthy' victims by police. Requests for assistance are 'often ignored or downplayed' and 'crimes against them are not investigated as thoroughly or prosecuted as vigorously' (Rudin, 2007, pp. 1, 36). The Ontario Human Rights Commission (2004, p. 57) noted from its discussions with Aboriginal people that, 'frequently, [they] talked about the uselessness of making complaints to police, human rights commissions or other complaint mechanisms because they would not be taken seriously or, worse yet, would be treated like suspects'.

Perhaps the most significant issue with under-policing identified in all the settler colonial states has been the failure to provide protection for Indigenous women who are victims of violence. The UN 
Committee on the Elimination of Racial Discrimination [CERD] has on several occasions expressed deep concern about the incidence of rape and sexual violence against American Indian and Alaska Native women, the insufficient will of federal and state authorities to take action, and in particular the need to ensure Indigenous women's right of access to justice (CERD, 2008, 2014).

Criminal victimisation is particularly high for Indigenous women in the settler colonial states. For example, the National Congress of American Indians (2014, p. 2) has noted that 'violence against Indian and Alaska Native women is at epidemic proportions and is one of the most horrific manifestations of the discriminatory legal system in the United States'. In relation to the Australian context, Indigenous women self-report experiencing physical or threatened violence at three times the rate of non-Indigenous women (Steering Committee for the Review of Government Service Provision [SCROGSP], 2016, p. 4.101). In some jurisdictions like the Northern Territory [NT] the rate of physical assault for Indigenous women is 11.4 times higher than the comparable rate for non-Indigenous women (SCROGSP, 2016, p. 4.102). The rate of Indigenous women reporting domestic and family violence by a current partner is also significantly higher than for non-Indigenous women (SCROGSP, 2016, p. 4.102). Indigenous women's hospitalisations for non-fatal family violence-related assaults are 32 times the rate for non-Indigenous females (SCROGSP, 2016, p. 4.103). Victimisation data in relation to Aboriginal women in Canada and Native American and Alaska Native women in the US is equally alarming, showing various levels of overrepresentation in reported incidents of murder, rape, and violent assaults, and physical and sexual maltreatment as a child. For example, Aboriginal women in Canada are twice as likely as Aboriginal men to be victims of violent crime, and three times more likely than non-Aboriginal women and men (Boyce, 2016).

The reality of under-policing in the case of Aboriginal women in both Australia and Canada has been highlighted in several reports. In Australia inadequate police responses to Indigenous women who are victims of violence have the result that women are reluctant to seek assistance from police (Aboriginal and Torres Strait Islander Social Justice Commission [ATSISJC], 2006). In Canada, Human Rights Watch (2013) reported on both abusive policing practices against Indigenous women and girls in Canada, and police failures to either protect Indigenous women and girls in cases of domestic violence and sexual assault, and/or failures to properly investigate disappearances and murders. Abusive police practices 
outlined in the report included the use of excessive force, assaults, inappropriate use of police dogs, pepper spray and tasers, and rape and sexual assault by police officers (Human Rights Watch, 2013, pp. 50-65). These incidences of abuse were compounded by the widely perceived failure of the police to protect Indigenous women from violence. The report found that, because of the injustices they have experienced, Indigenous women do not feel safe approaching the Royal Canadian Mounted Police [RCMP] when they have experienced violence (Human Rights Watch, 2013, pp. 8, 66).

The aptly-named Highway of Tears in northern British Columbia alone has an estimated 40 unsolved cases of missing and murdered Indigenous women (Human Rights Watch, 2013, p. 67). A report by the RCMP (2014, p. 7) found that over a thirty-year period, there were 1,181 police-reported incidents of Indigenous female homicide victims and unresolved missing Aboriginal female investigations. At the time of RCMP report there were 225 unsolved cases of either missing or murdered Indigenous women (2014, p. 7). The UN Committee for the Elimination of Discrimination against Women [CEDAW] found a 'grave violation' of the rights of Aboriginal women through insufficient and inadequate measures to protect Aboriginal women from gender-based violence, including disappearances and murders (CEDAW, 2015, p. 47). CEDAW recommended, inter alia, the establishment of a national public inquiry into the cases of missing and murdered Aboriginal women and girls, and the development of a national plan of action based on the findings of the proposed inquiry (CEDAW, 2015, p. 51). The former Canadian government rejected CEDAW's findings and recommendations. However, a new Canadian Liberal Government established the National Inquiry into Missing and Murdered Indigenous Women and Girls [NIMMIWG] in late 2016, with an Interim report published in late 2017 (NIMMIWG, 2017).

Repeatedly, critical and Indigenous writers have highlighted that the pressing priority in any campaign against violence in Indigenous communities, and specifically violence against Indigenous women, is for the de-colonisation of the formal response to the issue, including the implementation and resourcing of many more Indigenous developed and controlled programs, and meaningful support for Indigenous self-determination (for example, for Australia and Canada, see ATSISJC, 2011; Blagg, 2016; NIMMIWG, 2017). However, while we deem this activity necessary to enhance justice outcomes, it would likely fail to achieve any measurable reduction in social disorder without a thorough analysis of the effects of colonisation and state violence perpetrated against Indigenous peoples. 


\section{State Violence}

We see the examination of state violence as essential to any understanding of violence in Indigenous communities. Indigenous complaints of violence and abuse by criminal justice agencies, and in particular the police, are well documented. We noted above, complaints of abuse of Indigenous women and girls by police in Canada documented by Human Rights Watch (2013). In the Australian context, the two most extensive reports detailing violence and abuse by state agencies arose from the National Inquiry into Racist Violence [NIRV] (1991) and the Royal Commission into Aboriginal Deaths in Custody [RCADIC] (1991). It was clear from the evidence to both inquiries that the treatment of Indigenous people in the criminal justice system was an issue of national significance. The Federal Race Discrimination Commissioner at the time found that, 'Aboriginal-police relations have never been good, but they have now reached a critical point due to widespread police involvement in acts of racist violence, intimidation and harassment' (Moss, 1991, p. 5; see also Jackson (1988) for the experience of Maori in Aotearoa New Zealand).

The RCADIC also noted the prevalence of complaints made by Indigenous people concerning the incidence of police violence. The Commission felt that the widespread and discriminating nature of the complaints, the depth of feeling about the complaints and the history of violence, 'can leave no doubt that at various times and in many places, police "bashing" of Aboriginals has been a serious problem and has left a major barrier to Aboriginal trust of police' (Wootten, 1991, p. 279). The Commission believed that it was impossible to know the full extent of police violence.

Since both the RCADIC and NIRV inquiries of the early 1990s, there have been ongoing reports of police assaults of Indigenous people, and the use of excessive force including the inappropriate use of tasers and Oleoresin Capsicum (OC) spray/foam. The New South Wales [NSW] Ombudsman (2012) found that Indigenous people (who comprise a little over two per cent of the State's population) were nearly 30 per cent of all people tasered by police, and were also more likely to be subjected to multiple/continued taser use than other groups (p. 99). The Queensland Crime and Misconduct Commission (2005) noted that 23 per cent of OC spray subjects were Aboriginal and a further 10 per cent Torres Strait Islander or Pacific Islander in appearance (p. 25). Indigenous people comprise around 
three per cent of the State's population. For further examples, see also the Western Australian Corruption and Crime Commission (2012).

Cases of assault have led to successful civil and/or criminal litigation against police. For example, a fomer NSW police officer was ordered to pay $\$ 180,000$ compensation to an Indigenous man he had seriously assulted in a police station (Friend, 2002). In the Northern Territory [NT] a police officer was sentenced to nine months home detention for assauting an Indigenous person inpolice custody and attempting to erase the CCTV surveillance footage of the assault (McLaughlin, 2008). In NSW the Police Integrity Commission recommended that six officers be charged with criminal offences arising from the assault of an Indigenous man in police cells. The Commission found that, in addition to the assault, the six officers had committed perjury and fabricated evidence (Wells, 2014). As demonstrated in a number of significant inquiries, both policing strategies and police violence can lead to the death of death of Indigenous peoples.

\section{Indigenous Deaths in Custody}

The frequency and circumstances of Indigenous deaths in custody remain contentious. An Independent Police Conduct Authority [IPCA] review of police deaths in custody in Aotearoa New Zealand in the period 2000-2010 found that almost half the deaths involved Māori (IPCA, 2012, p 3). Thirty per cent of Māori deaths occurred while being restrained by police, which was three times higher than the proportion of deaths of people from a European background (IPCA, 2012, p 29). In the United States, according to Males (2014), the 'racial' group most likely to be killed by US law enforcement, on a per capita basis, are Native Americans, followed by African Americans, Latinos, Whites, and Asian Americans. More generally, Indigenous deaths in police and correctional custody continue to demonstrate the unnecessary use of arrest, violence and ill-treatment, and a basic neglect of a duty of care to Indigenous people held in custody (Cunneen \& Tauri, 2016, pp. 76-78).

Many Indigenous deaths in police custody arise from people being locked-up for minor offences. In discussing the deaths of Aboriginal people held in custody on 'drunk in public' charges in Ontario, Rudin (2007, p. 35) notes that, "what makes this process even more objectionable is that there is no reason to believe that placing a person who is very drunk in jail for a period of time to 'sleep it 
off' will actually prevent harm coming to the person'. Many Indigenous deaths in custody arise through a failure to exercise a required duty of care. This failure represents the 'violence of neglect'. It can be seen in the inaction of authorities who have specific responsibilities and duties towards people held in custody. More two and half decades ago the Australian RCADIC found that there was a significant failure by custodial authorities (both police and correctional authorities) to exercise a proper duty of care for Indigenous people. The Commission found that there was little understanding of the duty of care owed by custodial authorities, and that in some cases, the failure to offer proper care directly contributed to or caused deaths in custody.

More recent deaths of Indigenous people in police custody continue to illustrate the problems of police ill-treatment of Indigenous people. Three Australian examples are provided below. The NT coronial inquiry into the death in custody of Cedric Trigger in Alice Springs Police Watch House found that Trigger had been arrested by police for intoxication and trespassing. He was dragged inert from the police vehicle, face down and handcuffed, for several metres to the holding cell. He died, still face down, two hours later. The coroner reported that the 'few minutes captured on video demonstrated treatment of the deceased - or any person taken into the custody of the police - which was undignified and inappropriate. [Further] a person in the deceased's condition should not have been in the watch house, much less left in a holding cell with no risk assessment carried out' (Cavanagh, 2010, pp. 8-9). Two years later, the NT Coroner again reported on the death of an Indigenous man, Terence (Kwememtyaye) Briscoe, in Alice Springs Watch House in similar circumstances to Trigger. Kwementyaye was believed by police to be heavily intoxicated and was dragged along the floor by his limbs and left in a cell. He died at around 11:45pm and although others detained in the cell opposite him attempted to gain the attention of police officers, his body was not discovered until 1:45am. The Coroner found that, 'It is abundantly clear that there were multiple failings on the part of individual police officers and senior management that allowed Kwememtyaye's death to take place' (Cavanagh, 2012, p. 4). In 2014 twenty-two year old Ms Julieka Dhu died in police custody in a Western Australian police watch house after being arrested for unpaid fines. Ms Dhu complained to police about severe pain, vomiting and partial paralysis and was twice taken to hospital but on both occasions was sent back to prison. On the third occasion she was taken to hospital she was dying from septicaemia and 
pneumonia. Police believed her transfer to hospital was not urgent and reportedly told nursing staff she was 'faking' her illness. The coroner described her treatment by police as 'appalling' and 'unprofessional and inhumane' (Fogliani 2016: paras 880, 883).

The deaths of Trigger, Briscoe and Dhu show ongoing problems of ill-treatment and lack of duty of care by police when Indigenous people are taken into custody. All three were in custody for minor offences. Although suffering from serious medical conditions that ultimately led to their deaths, there was rough and inappropriate treatment, inadequate cell checks, failures in supervision and lack of access to medical services. The type of callous disregard for Indigenous well-being which was so extensively documented by the RCADIC remains a fundamental problem today.

Not all deaths in police custody arise from an absence of duty of care. Some appear deliberate. The so-called 'Saskatoon freezing deaths' (Saskatchewan, Canada) during the 1990s and early 2000s arose from the practice of members of the Saskatoon police arresting Aboriginal people for minor public order offences, driving them out of the city and abandoning them during winter months. A number of victims died from hyperthermia. In one case, the victim (Darrel Night) was able to survive. Two police officers were convicted as a result (Wright, 2004, p. 1). There was a judicial inquiry into one of the deaths (Neil Stonechild, who was seventeen year old at the time), more than a decade after his death had occurred. The Inquiry found that the initial police investigation was 'superficial and totally inadequate' (Wright, 2004, p. 212).

Given the history of Indigenous/police relations and the contemporary over-representation of Indigenous people in custody, situations where Indigenous people die as a result of police actions are undoubtedly controversial. At times the anger, frustration and fear arising from deaths in police custody results in a level of collective anger that erupts into riots. Two examples discussed below, in Redfern (NSW) and Palm Island (Queensland), reflect the depth of Indigenous community anger at perceived injustices by police and the ongoing use of violence by state functionaries to control and contain Indigenous peoples.

Seventeen-year-old 'TJ' Hickey died after impaling himself on a metal fence. TJ was classified as a 'high-risk offender' by police, which meant that he was subject to constant scrutiny. His bail requirement not to visit a particular housing estate where his mother resided imposed a legal condition 
that he would constantly breach. There was a widespread belief at the time that TJ was being chased by police when he died. On the night following his death a serious riot erupted in Redfern between Aboriginal people and police, which caused widespread injury (Cunneen, 2007, pp. 24-6). In 2004, Cameron Doomadgee died in police custody on Palm Island after being arrested for a minor public order offence. A protest riot occurred after Doomadgee's death, when post-mortem results revealed that he had been violently assaulted, suffering four broken ribs, a ruptured spleen and his liver almost cleaved in two. During the protest, the local police station and the courthouse were extensively damaged. Riot police were flown in to quell the unrest and Indigenous people were widely reported as being violent and lawless (Cunneen, 2007, pp. 26-28). What the discussion of state violence against Indigenous people demonstrates is the necessity for a reorientation away from an excessive focus on the 'pathological Indigenous individual' and the often assumed criminogenic nature of Indigenous cultural practices, to a critical analysis of the practices of the settler colonial state.

\section{Re-centring the Meaning and Analysis of Violence}

Across academic, media, public and political spheres, debates on Indigenous people and violence centre almost exclusively on the high rates of violence and abuse occurring in Indigenous communities, usually confined to issues such as family, domestic and other forms of interpersonal violence, child neglect and abuse, homicide and public disorder. However, with the exception of Indigenous and some non-Indigenous writers, this work defines the 'problem' of Indigenous violence within a narrow positivist frame. By this we mean, violence is removed from its broader context. We argue that two areas are particularly important for explaining high levels of violence in Indigenous communities, factors often neglected in 'mainstream' criminologies: the role of colonial violence; and the disavowal of Indigenous voices in understanding violence (epistemic violence).

Colonisation is and was a violent process. However, there are several problems in the current dominant non-Indigenous literature on violence. One is the view that colonial violence is something that can be discretely recognized but confined to the past. For example, Weatherburn (2014, p.150) in his discussion on Indigenous offending argues that colonisation and dispossession is only of historical interest. The problem is that there is no consideration of how colonial violence continues to inflect 
current institutional processes (such as state violence), and Indigenous understandings of and responses to the contemporary colonial state (such as, 'riots'). The continuation of colonial violence is not seen as 'violence' because the violence is normalised within the very heart of the state's foundational principles, that is, in its right to exercise sovereign power over the colonised. In addition, deeply entrenched colonial processes extended well beyond overt physical brutality. These processes have a significant impact on understanding the contemporary position of Indigenous people. In other words, the effects of colonialism materially impact on the marginalisation of Indigenous people; that is, on the day-to-day conditions under which Indigenous people live, including inadequate and overcrowded housing, poor health and lower life expectancy, poor educational and employment outcomes, racial discrimination and over-representation in the criminal justice system (see Cunneen \& Tauri, 2016, pp. 45-66). To demonstrate the links between the colonising enterprise and contemporary social outcomes for Indigenous peoples, such as over-representation in criminal justice, we turn attention to the imoact of racial discrimination.

\section{Racial Discrimination and Racist Violence}

In the context of the current discussion on Indigenous violence, we argue that racial discrimination is part of the deeply ingrained and ongoing experience of the colonised. Racism is a violent act. It is the active denial of the humanity of the affected person and their collective cultural identity, with negative impacts on social and emotional wellbeing. Racial discrimination has material outcomes in the denial of goods and services, such as access to medical services, housing and employment, and the further entrenchment of social and economic marginalisation. Racism can directly contribute to Indigenous anger and violent offending (Day et al., 2008, p.98), and also affects poorer physical and mental health. Public health literature shows a strong association between direct personal experiences of racism and ill health: 'The most consistent finding in this body of research is the association between racism and mental health conditions such as psychological distress, depression and anxiety' (Paradies et al., 2008, p. 3). We have also noted elsewhere the connection between racism and vigilantism on social media and the effect that it is having on the frequency of racist violent attacks against Indigenous people, particularly young people (Cunneen \& Russell, 2017). 


\section{Epistemic Violence and the Deficit Indigenie}

There is a substantial body of work written by Indigenous people on the problem of violence. However, their work, rooted in the experience of domination and social injustice, is largely ignored or disqualified. The valorisation of the voices, worldviews, subjectivities and perspectives of Indigenous people opens up an entirely different view of the problem of violence. In the words of two victimised and criminalised Canadian Aboriginal women:

There is no accidental relationship between our convictions for violent offences, and our histories as victims. As victims we carry the burden of our memories: of pain inflicted on us, of violence done before our eyes to those we loved, of rape, of sexual assaults, of beatings, of death. For us, violence begets violence: our contained hatred and rage concentrated in an explosion that has left us with yet more memories to scar and mark us (Aboriginal Justice Inquiry 1990, in Wesley, 2012, p. 23).

Contrary to narrow positivist perspectives on violence, Indigenous and critical writers consistently stress the complexity of the factors contributing to the violence occurring in Indigenous communities (see, for example, ATSISJC, 2011). The recognition of the central role colonial processes had, and continue to have, on the relationship between Indigenous people and violence is central to an Indigenous perspective:

Colonisation robbed groups of their power, autonomy and land. Living in a world where they are constantly portrayed as second-class citizens at best, but often not even citizens at all, it is not surprising that colonised groups have struggled to maintain their own identities and confidence in their abilities. Their anger and frustration about the injustices has manifested itself in violence, not 'vertically' towards the colonisers responsible for oppression, but 'laterally' towards their own community ... [to] those 
closest to us who do not represent the potent threat of the colonisers (ATSISJC, 2011, p.57).

\section{Conclusion}

By refusing to recognise the link between colonisation and the contemporary marginalisation of Indigenous Australians, and the validity of Indigenous knowledges and perspectives, one is left with a 'deficit-based' approach to the Indigenous 'problem'. For Weatherburn (2014), addressing unemployment, education, alcohol and other drug abuse, and child abuse is the key to reducing Indigenous violence and offending levels. While this might seem self-evident, the most important questions are how will this be done and by whose authority: the colonial state which has largely created the problem, or through Indigenous authority? This is the indeed the important political and empirical question: can we trust the state, one that continues to perpetuate violence against Indigenous peoples, to come up with meaningful solutions? Viewing social and economic marginality within the confines of a narrow positivist frame which ignores both the impact of colonisation and Indigenous understandings of violence, inevitably pathologises Indigenous people and communities as somehow deficit compared to the 'mainstream' (white) society. Such an approach invariably de-centres the settler colonial state from any critical analysis of the drivers of violence, either perpetated by or against, Indigenous peoples. Furthermore, such an approach ignores Indigenous social justice initiatives to resolve community problems and political demands for recognition and self-determination. In the health, child protection and criminal justice sectors, evidence shows that providing a 'voice' for disenfranchised peoples through participation in decision-making and governance leads to improved outcomes, as do holistic Indigenous programs aimed at family well-being, and culturally informed, Indigenous-designed treatment, rehabilitation and diversionary programs (SCRGSP, 2014, pp. 11.3940). 


\section{References}

Aboriginal and Torres Strait Islander Social Justice Commission [ATSISJC]. (2006). Ending family violence and abuse in Aboriginal and Torres Strait Islander communities. Sydney: Australian Human Rights Commission.

ATSISJC. (2011). Social justice report 2011. Sydney: Australian Human Rights Commission.

Ben-Porat, G. (2008). Policing multicultural states: Lessons from the Canadian model, Policing and Society, 8, 4, 411-425.

Blagg, H. (2016). Crime, aboriginality and the decolonisation of justice. 2nd edition. Annandale: Federation Press.

Boyce, J. (2016). Victimization of Aboriginal people in Canada, 2014. Ottawa: Statistics Canada. Retrieved from: http://www.statcan.gc.ca/pub/85-002-x/2016001/article/14631-eng.htm.

Cavanagh, G. (2010). Inquest into the death of Cedric Trigger [2010] NTMC 036. Alice Springs: Coroner's Court of the Northern Territory. Retrieved from: http://www.nt.gov.au/justice/courtsupp/coroner/documents/A00022009Trigger.pdf.

Cavanagh, G. (2012). Inquest into the death of Terence Daniel Briscoe [2012] NTMC 032. Alice Springs: Coroner's Court of the Northern Territory. Retrieved from: http://www.nt.gov.au/justice/courtsupp/coroner/documents/2012_findings/A00052012_Briscoe.pdf. Committee on the Elimination of Discrimination Against Women [CEDAW] (2015), Report of the inquiry concerning Canada of the Committee on the Elimination of Discrimination Against Women. CEDAW/C/OP.8/CAN/1. Geneva: United Nations.

Committee on the Elimination of Racial Discrimination [CERD]. (2008). Concluding observations of the Committee on the Elimination of Racial Discrimination: United States of America, Seventy-second Session. Geneva: United Nations.

CERD. (2014). Concluding observations of the Committee on the Elimination of Racial Discrimination: United States of America, Eightieth Session, Geneva: United Nations.

Corruption and Crime Commission, Western Australia. (2012). Charges to be considered over tasering of Kevin Spratt. Media Release. Perth: Corruption and Crime Commission. Retrieved from 
https://www.ccc.wa.gov.au/publications/media-releases/page/charges-be-considered-over-taseringkevin-spratt.

Crime and Misconduct Commission, Queensland. (2005). Oleoresin capsicum (OC) spray use by Queensland police. Brisbane: Crime and Misconduct Commission.

Cunneen, C. (2001). Conflict, Politics and Crime: Aboriginal Communities and the Police, Sydney: Allen and Unwin

Cunneen, C. (2007). Riot, resistance and moral panic: Demonising the colonial other. In S. Poynting and G. Morgan (Eds). Outrageous! Moral panics in Australia (pp. 20-29). Hobart: ACYS Publishing. Cunneen, C. \& Russell, S. (2017). Social media, vigilantism and indigenous people in Australia. Oxford Research Encyclopedia of Criminology and Criminal Justice, Published online Sep 2017. doi: 10.1093/acrefore/9780190264079.013.109.

Cunneen, C. \& Rowe, S. (2016). Reconsidering the Relationship Between Indigenous People and Violence. In J. Stubbs and S. Tomsen (Eds). Australian Violence. Crime, Criminal Justice and Beyond (pp. 106-124). Leichhardt: Federation Press

Cunneen, C., \& Tauri, J. (2016). Indigenous criminology. Bristol: Policy Press.

Day, A., Davey, L., Wanganeen, R., Howells, K., De Santolo, J. \& Nakata, M. (2008). The significance of context: Stories from South Australia. In A. Day, M. Nakata \& K. Howells (Eds). Anger and Indigenous Men (pp. 88-102). Leichhardt: Federation Press.

Deckert, A. (2015). Criminologists, duct tape, and Indigenous people: Quantifying the use of silencing research methods, International Journal of Comparative and Applied Criminal Justice, May, online. Fogliani, D. (2016). Inquest into the death of Julieka Ivanna Dhu (11020-14). Perth: Coroner's Court of Western Australia.

Friend, S. (2002). A check on police brutality: Vernon Moran, the state of New South Wales and the police. Indigenous Law Bulletin, 5, 16, 20-21.

Human Rights Watch. (2013). Those who take us away. Abusive policing and failures in protection of Indigenous women and girls in Northern British Columbia, Canada. Human Rights Watch. Retrieved from: http://www.hrw.org/sites/default/files/reports/canada0213webwcover_0.pdf. 
Independent Police Conduct Authority [IPCA]. (2012). Thematic report: Deaths in custody - A ten year review. Wellington: Independent Police Conduct Authority.

International Indian Treaty Council. (2007). Racial discrimination against Indigenous peoples in the United States, consolidated Indigenous shadow report to the UN Committee on the Elimination of Racial Discrimination. San Francisco: International Indian Treaty Council.

Jackson, M (1988) Maori and the criminal justice system, part I. Department of Justice: Wellington.

Males M. 2014. Who are police killing? Center on Juvenile and Criminal Justice. Retrieved from: http://www.cjcj.org/news/8113.

McLaughlin, M. (2008). Tenant Creek officer convicted of assaulting prisoner. 7.30 Report, ABC TV. 12 June 2008. Retrieved from: http://www.abc.net.au/7.30/content/2007/s2273195.htm.

Ministry of Justice. (2015). 2014 New Zealand crime and safety survey: Main findings report. Wellington: Ministry of Justice.

Moss, I. (1991). The report of the national inquiry into racist violence. Aboriginal Law Bulletin, 1, 49, $3-5$.

National Congress of American Indians. (2014). Violence against American Indian and Alaska Native women - United States' violations of the International Convention on the Elimination of All Forms of Racial Discrimination. Retrieved from: http://tbinternet.ohchr.org/Treaties/CERD/Shared\%20Documents/USA/INT_CERD_NGO_USA_175 49_E.pdf.

National Indian Youth Council. (2013). Commentary on the periodic report of the United States of America on the elimination of racial discrimination pursuant to the International Convention, Retrieved from:

http://tbinternet.ohchr.org/Treaties/CERD/Shared\%20Documents/USA/INT_CERD_NGO_USA_176 38_E.pdf Accessed 16 June 2015.

National Inquiry into Missing and Murdered Indigenous Women and Girls [NIMMIWG]. (2017). Our women and girls are sacred. Interim Report. Ottawa: National Inquiry into Missing and Murdered Indigenous Women and Girls. 
National Inquiry into Racist Violence [NIRV]. (1991). Racist violence. Sydney: Human Rights and Equal Opportunity Commission.

New South Wales Ombudsman. (2012). How are taser weapons used by the NSW Police Force? Sydney: New South Wales Ombudsman.

Ontario Human Rights Commission. (2004). Paying the price: The human cost of racial profiling. Toronto: Ontario Human Rights Commission.

Paradies, Y., Harris, R. \& Anderson, I. (2008). The impact of racism on indigenous health in Australia and Aotearoa: Towards a research agenda. Discussion Paper No. 4. Darwin: Cooperative Research Centre for Aboriginal Health.

Perry, B. (2008). Silent victims: Hate crime against Native Americans. Tuscon: University of Arizona Press.

Perry, S. (2004). American Indians and crime. A BJS statistical profile, 1992-2002. Washington DC: US Department of Justice, Office of Justice Programs.

Royal Canadian Mounted Police [RCMP]. (2014). Missing and murdered Aboriginal women. A national operational overview. RCMP. Retrieved from: www.rcmp-grc.gc.ca/pubs/mmaw-faapdeng.pdf.

Royal Commission into Aboriginal Deaths in Custody [RCADIC]. (1991). Royal commission into aboriginal deaths in custody. National report. Canberra: Australian Government Publishing Service. Royal Commission on Aboriginal Peoples. (1996). Bridging the cultural divide. Ottawa: Minister of Supply and Services Canada.

Rudin, J. (2007). 'Aboriginal peoples and the criminal justice system', paper prepared for the Ipperwash Inquiry.

Retrieved from: http://www.archives.gov.on.ca/en/e_records/ipperwash/policy_part/research/pdf/Rudin.pdf. South Australian Council of Social Services. (2015). Justice or an unjust system? Aboriginal overrepresentation in South Australia's juvenile justice system. Unley (SA): South Australian Council of Social Services

Spivak, G. C. (1988). Can the Subaltern speak? In C. Nelson \& L. Grossberg (Eds.) Marxism and the interpretation of culture (pp. 271-313). London: Macmillan. 
Steering Committee for the Review of Government Service Provision [SCRGSP]. (2014). Overcoming Indigenous disadvantage. Melbourne: Productivity Commission.

SCROGSP. (2016). Overcoming Indigenous disadvantage-key indicators 2016. Melbourne: Productivity Commission.

Tauri, J. (2014). Criminal Justice as a Colonial Project in Settler-Colonialism, African Journal of Criminology and Justice Studies, 8, 1, 20-37.

Tauri, J (2016). The State, the Academy and Indigenous Justice: A Counter-Colonial Critique. PhD thesis, University of Wollongong.

United Nations. (2009). State of the world's indigenous peoples. New York: United Nations.

Walter, M. (2016). Indigenous peoples, research and ethics. In M. Adorjan \& R. Ricciardelli (Eds.), Engaging with ethics in international criminological research (pp. 87-105). London: Routledge.

Walter, M. \& Andersen, C. (2013). Indigenous statistics: A quantitative methodology. Los Angeles: Left Coast Press.

Weatherburn, D. (2014). Arresting incarceration: Pathways out of indigenous imprisonment. Canberra: Aboriginal Studies Press.

Wells, J. (2014). Four police officers to stand trial over the bashing of Aboriginal man Corey Barker. ABC. 16 October 2014. Retrieved from: http://www.abc.net.au/news/2014-10-16/four-police-officersto-stand-trial-over-the-bashing-of-aborigi/5818188.

Wesley, M. (2012). Marginalised: The aboriginal women's experience in federal corrections. Ontario: Aboriginal Corrections Policy Unit.

Wootten, H. (1991). Royal commission into aboriginal deaths in custody, regional report of inquiry in New South Wales, Victoria and Tasmania. Canberra: Australian Government Publishing Service. Wright (2004). 